\title{
Frontiers of International Law: Counteracting the Exercise of Extraterritorial Jurisdiction
}

Keywords: countermeasures; European Union; extraterritorial jurisdiction; retorsion measures; United States.

On 22 November 1996, the Council of the European Union adopted a framework regulation and agreed to joint action to 'protect' the interests of the European Union and its citizens against the extraterritorial application of legislation by non-member states. ${ }^{1}$ These measures were adopted in response to the extraterritorial application of certain measures by the United States, concerning trade with and investment in Cuba, as well as investment in Iran and Libya. ${ }^{2}$ These United States measures apply to all natural and legal persons irrespective of their nationality, residency, or place of activity. Thus, even nationals of a member state of the European Union residing and active in the European Union must comply with the United States measures. The enactment of this legislation marks a new episode in the on-going battle between the United States and the European Union over the frontiers of a state's (or an international organization's) jurisdiction to prescribe. This time, however, the European Union counteracted by the adoption of measures which can partly be characterized as

1. See Council Regulation 2271/96/EC of 22 November 1996 Protecting Against the Effects of the Extra-Territorial Application of Legislation Adopted by a Third Country, and Actions Based Thereon or Resulting Therefrom, OJEC 1996, L 309/1; and Joint Action of 22 November 1996 Adopted by the Council on the Basis of Articles J.3 and K.3 of the Treaty on European Union Concerning Measures Protecting Against the Effects of the Extra-Territorial Application of Legislation Adopted by a Third Country, and Actions Based Thereon or Resulting Therefrom, OJEC 1996, L 309/7.

2. See National Defense Authorization Act for Fiscal Year 1993, Title XVII 'Cuban Democracy Act 1992'; Cuban Liberty and Democratic Solidarity (LibERTAD) Act of 1996; Iran and Libya Sanctions Act of 1996; Code of Federal Regulations, Ch. V, Part 515 - Cuban Assets Control Regulations. 
retorsion measures and partly as countermeasures. The adoption of these measures by the European Union raises questions with respect to the legitimacy of the retorsion measures and the legality of the countermeasures.

The operative provisions of the Regulation provide for the submission of information to the Commission of the European Communities on the application of the laws listed in the Annex to it (Article 2); non-recognition and non-execution of foreign judgments that are based on such laws (Article 4); obligatory non-compliance with such laws and acts based on them with the possibility of a waiver ( $\Lambda$ rticle 5 ); and the right to "claw back' damage resulting from the application of such laws (Article 6). Pursuant to Article 11, the Regulation is, inter alia, applicable to:

1. any natural person being a resident in the Community and a national of a member state on the understanding that 'being a resident in the Community' means being legally established in the Community for a period of at least six months within the twelvemonth perind immediately prior to the date on which, under the Regulation, an obligation arises or a right is exercised;

2. any legal person incorporated within the Community; and

3. an other natural person being a resident in the Community, unless that person is in the country of which he is a national.

'I'hus, the Regulation also applies to United States nationals which reside in the Community, unless they are physically in the United States. Violation of Articles 2 and 5 is to be subject to sanctions by the member states that are effective, proportional, and dissuasive (Article 9). At present, the Annex only contains laws adopted by the United States on trade with Cuba and on investment in Cuba, I ihya, and Iran. The Joint Action allows member states to adopt supplementary measures to extend protection to interests not covered by the Regulation.

The application of Articles 5 (to the extent that it requires private persons to abide by the Regulation) and 6 may entail some results which are questionable for reasons of legal efficiency and fairness. Natural and legal persons bound by the Regulation may find themselves in a catch- 22 as they may have to abide by two sets of legislation which are outright contradictory. For example, a national of a member state of the European Union who resides in the United States or a national of the United States who resides in the European Union is bound by Article 5 of the Regulation that 
orders him or her not to comply with a law by which he or she is also bound by virtue of nationality or residency. The Regulation thus puts lawabiding citizens in a lose-lose situation: if a Community resident has been offered a golden business opportunity in Cuba that involves tainted property, he should accept the offer on the basis of the Regulation and reject it on the basis of the United States law concerned. Article 6 may result in a perpetuum mobile as one can claw back in a member state of the European Union what one has lost in the United States - only constrained by the payment of legal fees. One may and should question the legitimacy of such measures, but the prescription of contradictory legislation does not in itself constitute a violation of international law. It is merely a measure of retorsion.

Articles 4 and 5, however, may appear to be a countermeasure to the extent that they impose obligations on public persons. Compliance with these articles may result in the violation of multilateral and bilateral treaties to which the United States and one or more member states of the European Union are a party. With the exception of the Iran and Libya Sanctions Act of 1996, the application of the disputed United States measures may result in court cases in the United States arising out of civil actions in connecrion with the submission of clains for compensation or administrative sanctions in connection with the violation of the trade or investment embargoes. ${ }^{3}$ For example, in civil cases involving claims for compensation under the - presently suspended ${ }^{4}$ - relevant provisions of the United States Cuban Liberty and Democratic Solidarity (LIBERTAD) Act, a member state may find that the application of the Regulation conflicts with other international obligations incumbent on that state, e.g. the 1965 Convention on the Service Abroad of Judicial and Extrajudicial Documents in Civil or Commercial Matters or the 1970 Convention on the Taking of Evidence Abroad in Civil or Commercial Matters to which the United States as well as most of the member states of the European Union are a party. ${ }^{5}$ These treaties were concluded before the adoption of the Regulation but after the entry into force of the 1957 Treaty establishing the European Economic

\footnotetext{
3. Pursuant to S. 11 of the Iran and Libya Sanctions Act of 1996, "[a] determination to impose sanctions under this Act shali not be reviewable in any court".

4. The submission of claims was suspended for the second time for six months by President Clinton on 3 January 1997. See NRC Handelsblad, 4 January 1997, at 13.

5. See 1966 Dutch Treaty Series (Trb.) 91, and 1979 Trb. 38, respectively.
} 
Community (EC Treaty). ${ }^{6}$ The EC Treaty does not contain a conflict-oftreaties rule governing the simultaneous application of the EC Treaty and another treaty. Although no such case has ever been presented to the Court of Justice of the European Communities, it is reasonable and accepted to apply Article $234 \mathrm{EC}$ analogously if the member states are competent with respect to the subject-matter of a treaty at the time of its conclusion. As for the treaties mentioned above, it is beyond any doubt that the member states were still competent at the time of their conclusion.

Thus, il appears that Connumity law permits member states to refrain from compliance with the Regulation in particular cases. In contrast, compliance with the Regulation may result in the violation of a treaty obligation vis-à-vis the United States. However, it is a customary rule of international law that

[t]he wrongfulness of an act of a State not in conformity with an international obligation of that State is precluded if the act constitutes a measure legitimate under international law against that other State, in consequence of an internationally wrongful act of that other State. ${ }^{7}$

Thus, a member state of the European Union may invoke the law of state responsibility to defend non-compliance with a treaty obligation. For a countermeasure to be lawful, there must have been a preceding internationally wrongful act. In this respect, the views of the Council of the European Union are pertinent. In the preambles to both the Regulation and the Joint Action, it is stated that by their extraterritorial application the laws, regulations and other legislative instruments adopted by a certain third country "violate international law" ${ }^{8}$ Before putting this allegation to the test, other conditions for the lawful application of countermeasures will be reviewed.

Recourse to countermeasures is only admissible to secure cessation and/or reparation of a preceding internationally wrongful act. In order to ensure that a countermeasure is used to further this objective, it may only be applied if international remedies have been exhausted and if it is proportional to the preceding internationally wrongful act and its effects. ${ }^{9}$

6. See 295 UNTS 23.

7. Art. 30 of the Draft Articles on State Responsibility, as provisionally adopted by the International Law Commission on first reading in 1996 , reproduced in UN Doc. A/CN.4/ L.528/Add.2 (1996); see also id., Art. 47(1).

8. See preambles to Council Regulation and Joint Action, supra note 1.

9. See Arts. 48 and 49 of the ILC's Draft Articles on State Responsibility, supra note 7. 
Pursuant to the first requirement, an injured state must first seek to resolve the dispute by diplomatic means and if this does not lead to an amicable settlement, by recourse to other binding dispute settlement procedures in force. In the present case, the European Union did enter into negotiations with the United States. These negotiations are still pending, but have, so far, not been very successful. As for binding dispute settlement procedures, the 1994 Marrakesh Agreement Establishing the World Trade Organization (WTO) is the only one that can be invoked unilaterally by the European Union. ${ }^{10}$ On 20 November 1996, at the request of the European Community following the required consultations, the WTO Dispute Settlement Body established a panel to review the legality of the trade measures with respect to Cuba under the 1994 General Agreement on Tariffs and Trade (GAT'T). ${ }^{11}$

If an injured state would have to await the outcome of often lengthy dispute-settlement procedures, however, irreparable damage may have already been caused to the interests of that state by the time justice is done. Thcrefore, an injured state is entitled to adopt unilateral interim measures of protection, provided that it, firstly, has attempted to resolve the dispute by negotiations and pursues available dispute-settlement procedures and, secondly, countermeasures adopted at this stage have a protective purpose and are likely to prove reversible. ${ }^{12}$ It is submitted that the measures adopted by the European Union meet this requirement. Their purpose is to protect European Union interests "by removing, neutralising, blocking or otherwise countering the effects of the foreign legislation concerned", and no more than that.

Secondly, for a countermeasure to be lawful, it may not be "out of proportion to the degree of gravity of the internationally wrongful act and the effects thercof on the injured State". ${ }^{14}$ It may be considered apparent that. the satisfaction of this requirement follows from the protective purpose of the measures adopted by the European Union.

10. See 33 ILM 112 (1994).

11. See 33 ILM 112 (1994). Cf. O.Q. Swak-Goldman, W'bo Dffincs Mombers' Secstrity Interest in the WTO?, 9 LJIL 361 (1996), on the applicability of GATT's security exception to this case.

12. See Art. 48(1), second sentence, of the ILC's Draft Articles on State Responsibility, supra note 7; and the commentary thereto, reproduced in UN Doc. A/CIN.4/L.528/Add.3 (1996).

13. See Preamble to the Council Regulation, supra note 1.

14. See Arts. 48 and 49 of the ILC's Draft Articles on State Responsibility, supra note 7. 
Since the Regulation and the Joint Action thus appear to be aimed at the undoing of the perceived internationally wrongful act of the United States, they are in conformity with an essential requirement for their lawfulness as a countermeasure. However, the International Law Commission has warned that

an injured State which resorts to countermeasures based on its unilateral assessment of the situation does so at its own risk and may incur responsibility for an unlawful act in the event of an incorrect assessment. ${ }^{15}$

Therefore, it is necessary to scrutinize the allegation of the Council of the European Union that the United States measures in dispute violate international law, since the lawfulness of compliance with Articles 4 and 5 of the Regulation by public persons depends on the existence of a preceding internationally wrongful act of the United States. As the Iran and Libya Sanctions Act of 1996 cannot give rise to court cases, ${ }^{16}$ the analysis can be limited to the measures adopted by the United States with respect to Cuba in $1996 .{ }^{17}$ To justify the establishment of a cause for civil action for the wrongful taking of property and the exclusion of aliens 'trafficking' in tainted property, the United States Cuban Liberty and Democratic Solidarity (LIBERTAD) Act of 1996, after noting that " $[t]$ he international judicial system, as currently structured" does not provide for fully effective remedies to undo unlawful expropriations, states that

"[i]nternational law recognizes that a nation has the ability to provide for rules of law with respect to conduct outside its territory that has or is intended to have substantial effect within its territory" ${ }^{18}$

Thus, the United States invokes the effects doctrine to justify its exercise of extraterritorial jurisdiction. This reveals the real nature of the dispute, viz. the on-going battle between the United States and the European Union over the frontiers of a state's (or an international organization's) jurisdiction. In the present case, politics compelled the Council of the European

15. Conmentary to Arc, 47 of the LLC's Draft Articles on Stace Responsibiliry, UN Doc. A/CN.4/L.528/Add.3 (1996), at 3.

16. See note 3 , supra.

17. See, on the international legality of the measures, A.F. Lowenfeld, Congress and Cuba: The Helms-Burton Act, 90 AJIL 419 (1996); B.M. Clagett, Title III of the Helms-Burton Act Is Consistent With International Law, 90 AJIL 434 (1996); and B.M. Clagett, A Reply to Professor Lowenfeld, 90 AJIL 641 (1996).

18. S. $301(8-9)$. 
Union to quickly counteract the exercise of extraterritorial jurisdiction by the United States. This has resulted in the adoption of measures by the Council, of which the international legality of certain provisions is disputable, and of which the legitimacy of others may, most certainly, be called into question. The adoption of the Regulation and the Joint Action may have been celehrated as a glorious demonstration of European unity, but the provisions themselves are a legal anomaly and should be reconsidered.

René Lefeber 